\title{
Retrievable stent thrombectomy in the treatment of acute ischemic stroke: Analysis of a revolutionizing treatment technique
}

\section{Citation}

Walcott, Brian P., Kevin M. Boehm, Christopher J. Stapleton, Brijesh P. Mehta, Brian V. Nahed, and Christopher S. Ogilvy. 2013. "Retrievable Stent Thrombectomy in the Treatment of Acute Ischemic Stroke: Analysis of a Revolutionizing Treatment Technique." Journal of Clinical Neuroscience 20 (10) (October): 1346-1349. doi:10.1016/j.jocn.2013.03.015.

\section{Published Version}

doi:10.1016/j.jocn.2013.03.015

\section{Permanent link}

http://nrs.harvard.edu/urn-3:HUL.InstRepos:37034628

\section{Terms of Use}

This article was downloaded from Harvard University's DASH repository, and is made available under the terms and conditions applicable to Other Posted Material, as set forth at http:// nrs.harvard.edu/urn-3:HUL.InstRepos:dash.current.terms-of-use\#LAA

\section{Share Your Story}

The Harvard community has made this article openly available.

Please share how this access benefits you. Submit a story.

Accessibility 


\title{
Retrievable stent thrombectomy in the treatment of acute ischemic stroke: Analysis of a revolutionizing treatment technique
}

\author{
Brian P. Walcott ${ }^{\mathrm{a}, 1}$, Kevin M. Boehm ${ }^{\mathrm{a}, \mathrm{b}, 1}$, Christopher J. Stapleton ${ }^{\mathrm{a}}$, Brijesh P. Mehta $^{\mathrm{c}}$, \\ Brian V. Nahed ${ }^{\mathrm{a}}$, and Christopher S. Ogilvy ${ }^{\mathrm{a}}$ \\ aDepartment of Neurosurgery, Massachusetts General Hospital and Harvard Medical School, 55 \\ Fruit Street, White Building Room 502, Boston, MA 02114, USA \\ bYale University, New Haven, CT, USA \\ 'Department of Interventional Neuroradiology, Massachusetts General Hospital and Harvard \\ Medical School, Boston, MA, USA
}

\section{Abstract}

Acute ischemic stroke resulting from intracranial vessel occlusion is associated with high morbidity and mortality. The mainstays of therapy are fibrinolytics and mechanical thrombectomy in properly selected patients. A new Food and Drug Administration-approved technology to perform thrombectomy, retrievable stenting, may provide superior revascularization rates and improved patient outcomes. We analyzed the cumulative human experience reported for the Trevo Pro Retrieval System (Stryker, Kalamazoo, MI, USA) and the Solitaire FR Revascularization Device (ev3, Irvine, CA, USA) as the definitive treatment for acute ischemic stroke. A literature search was undertaken to identify studies using the retrievable stents published up to September 2012. Nineteen studies identified a total of 576 patients treated with either the Trevo $(n=221)$ or Solitaire $(n=355)$ devices. Pooled data analysis identified baseline National Institutes of Health Stroke Scale scores of $18.5 \pm 0.289$ (standard error of the mean) and 17.9 \pm 0.610 , and time to recanalization of $53.9 \pm 23.6$ minutes and $59.0 \pm 8.0$ minutes for the Trevo and Solitaire groups, respectively. Recanalization was variably defined by individual studies, most commonly achieving at least a thrombolysis in cerebral infarction score of $2 \mathrm{a}-3$ or a thrombolysis in myocardial infarction score of $2-3$. Revascularization $(83 \%, 82 \%)$, mortality $(31 \%, 14 \%)$, hemorrhage ( $8 \%$, $6 \%$ ), device complications $(5 \%, 6 \%)$, and good patient outcomes $(51 \%, 47 \%)$ were found with the Trevo and Solitaire devices, respectively. Preliminary analysis reveals excellent clinical outcomes for retrievable stent technology. This may be attributable to both high rates of revascularization with a relatively short time to perfusion restoration.

\footnotetext{
(c) 2013 Elsevier Ltd. All rights reserved.

*Corresponding author. Tel.: +1 617726 2000; fax: +1 617643 4113. walcott.brian@mgh.harvard.edu (B.P. Walcott)..

${ }^{1}$ These authors have contributed equally to the manuscript.
}

Publisher's Disclaimer: This is a PDF file of an unedited manuscript that has been accepted for publication. As a service to our customers we are providing this early version of the manuscript. The manuscript will undergo copyediting, typesetting, and review of the resulting proof before it is published in its final citable form. Please note that during the production process errors may be discovered which could affect the content, and all legal disclaimers that apply to the journal pertain.

Conflicts of Interest/Disclosures

The authors declare that they have no financial or other conflicts of interest in relation to this research and its publication. 


\section{Keywords}

Endovascular; Ischemia; Neurosurgery; Solitaire; Stent; Stroke; Trevo

\section{Introduction}

Acute cerebral ischemia is a major cause of morbidity and mortality worldwide. 1-3 The mainstay of medical therapy is intravenous administration of recombinant tissue plasminogen activator (rt-PA) to establish revascularization (reperfusion). ${ }^{4}$ Despite this, the use of rt-PA is successful in only $46.2 \%$ of patients when administered intravenously. ${ }^{5,6}$ For patients that do not qualify for rt-PA, or for whom it is not successful, endovascular therapy can be considered. ${ }^{7}$

In addition to intra-arterial rt-PA ${ }^{8}$, endovascular therapies including mechanical thrombectomy devices have evolved to locally obliterate the occlusive thrombus. In 2004, the Merci Retriever (Concentric Medical, CA, USA) was approved by the US Food and Drug Administration (FDA) for mechanical thrombectomy in stroke patients. ${ }^{9}$ The retriever has a corkscrew-shaped coil capable of extracting clots from occluded vessels and into the microcatheter. Another mechanical device, the Penumbra System (Penumbra, CA, USA) is an alternative approach to mechanical thrombectomy. During treatment with the Penumbra, a separator (microwire controlled by the operator) is used to dislodge the clot, while aspiration is applied through a proximal microcatheter. ${ }^{10}$ Though revascularization rates with these devices are excellent ${ }^{7,10-12}$, clinical outcomes have been discordant. ${ }^{13,14}$ While revascularization rates of $48 \%$ can be achieved with the Merci Retriever, a modified Rankin scale (mRS) score of $\leq 2$ is observed for only $27.7 \%$ of patients at 90 days. ${ }^{11}$ Similarly, the Penumbra yields a revascularization rate of $82 \%$, but only $25 \%$ of patients have a mRS $\leq 2$ at 90 days..$^{15}$

A new generation of endovascular stroke therapy is now focused on a revolutionary class of devices known as "stentrievers." Rather than extracting the clot using a corkscrew device (Merci Retriever) or aspirating the clot (Penumbra System), stentrievers function by first deploying a stent within the clot itself. After allowing time for sufficient stent integration into the clot, the combination of the two is removed. This results in immediate, partial flow restoration as the stent expands, as compared to previous generation devices that require clot extraction to establish flow restoration. The devices currently approved by the FDA are the Solitaire FR Revascularization Device (Solitaire; ev3, Irvine, CA, USA) and the Trevo Pro Retrieval System (Trevo; Stryker, Kalamazoo, MI, USA). Here, we review the initial experience with these two members of this revolutionizing class of devices used as single modality treatment of acute ischemic stroke.

\section{Methods}

A PubMed and MEDLINE keyword search was conducted to identify studies reporting treatment of acute ischemic stroke with the Solitaire or Trevo devices, published up to September 2012. Abstracts were reviewed and prioritized; full papers were reviewed, and references were obtained as appropriate. Inclusion criteria also required that studies utilized these devices in human subjects. Exclusion criteria consisted of case studies, studies on nonhumans, utilization of multi-modal endovascular treatment, and the use of these devices for extra-cranial vascular occlusion. For each study, the device used, number of patients, study design (prospective or retrospective), and median baseline National Institutes of Health Stroke Scale (NIHSS) scores were recorded. Further data extracted included the revascularization rate, as was defined by the scale used by individual study groups to 
indicate success. ${ }^{16-18}$ Additionally, the mean or median time from groin puncture to revascularization, symptomatic hemorrhage rate, device-related complication rate, mortality at follow-up, mRS score at follow-up, and use of intra-arterial fibrinolytics was recorded. Total final recanalization rate, mortality rate, hemorrhage rate, and percentage of patients with $\mathrm{mRS} \leq 2$ for each device were calculated using a weighted average of all available studies.

\section{Results}

In total, 26 manuscripts were identified that reported the use of the Trevo or Solitaire devices. Of these, nine were excluded: one due to incorporation of study subjects into a more contemporary series, six for the use of multi-modal endovascular treatments, one due to its nature as a case study, and one because of the emphasis on extra-cranial vascular occlusion.

The 19 included studies identified a total of 576 patients treated with either the Trevo Pro Retrieval System $(\mathrm{n}=221)^{19-22}$ or the Solitaire FR Revascularization Device $(\mathrm{n}=$ $355) .{ }^{20,23-35}$ Pooled data analysis identified median baseline NIHSS scores of $18.5 \pm 0.289$ (standard error of the mean) and $17.9 \pm 0.610$, and time to recanalization of $53.9 \pm 23.6$ minutes and $59.0 \pm 8.0$ minutes in the Trevo and Solitaire groups, respectively. Recanalization was variably defined as specified by individual studies, most commonly achieving at least a thrombolysis in cerebral infarction (TICI) score of $2 \mathrm{a}-3$ or a thrombolysis in myocardial infarction score of $2-3$. Revascularization $(83 \%, 82 \%)$, mortality $(31 \%, 14 \%)$, hemorrhage $(8 \%, 6 \%)$, device complications $(5 \%, 6 \%)$, and good patient outcomes $(51 \%, 47 \%)$ were found for the Trevo and Solitaire devices, respectively (Table 1,2).

\section{Discussion}

Retrievable stents, known as stentrievers, are a novel technology to perform a mechanical thrombectomy. Unlike prior devices that required clot extraction to achieve reperfusion, stentrievers facilitate the immediate restoration of blood flow via expansion of a stent within the clot. The stent integration into the clot also allows for subsequent clot and stent extraction, without any need for permanent device implantation.

In one of the largest randomized trials, angiographic, safety, and clinical outcomes were better for the Solitaire device compared with the Merci device. ${ }^{33}$ Fundamentally, it is advantageous to utilize thrombectomy devices with faster revascularization times, as the old adage "time is brain" is important when maximizing clinical outcomes. ${ }^{36}$ Other technical aspects of stentrievers, such as their unlikelihood to result in distal embolization during treatment, may contribute to the improved clinical outcome. While the results of the study by Saver et al. are promising ${ }^{33}$, (along with similar results identified in other studies), cautious optimism must be exercised with any proposed radical change in clinical management. It is increasingly being recognized that any single source, no matter the quality of the study, should not be used to guide clinical management. ${ }^{37,38}$ The "gold standard" for clinical efficacy is really the reproducibility of any comparison between groups. With this in mind, stentrievers are on a trajectory to result in a paradigm change in the treatment of stroke.

Currently, two clinical trials are registered at ClinicalTrials.gov for the Trevo device, both of which are complete. The TREVO study (NCT01088672) was completed in September 2012 and the final results are yet to be published. The TREVO2 study (NCT01270867) recently published its results, establishing stentrievers as highly effective thrombectomy devices. ${ }^{19}$ 
Multiple clinical trials, encompassing hundreds of patients, are also ongoing or planned for the Solitaire device (NCT01657461, NCT00359424, NCT01692379, NCT01327989, NCT01492725). Stentriever technology is poised to become the preferred mechanical thrombectomy device in most patients pending evaluation by further randomized trials.

\subsection{Illustrative patient}

An 83-year-old woman with a history of atrial fibrillation, hypertension, and diabetes mellitus presented to an outside hospital emergency department (ED) 2 hours after acuteonset right face, arm, and leg weakness with dysarthia and aphasia. Her NIHSS score on arrival was 15. Intravenous rt-PA was administered at $0.9 \mathrm{mg} / \mathrm{kg}$ over 1 hour beginning 2 hours and 18 minutes after her symptom onset. The patient was subsequently transferred to our institution's ED, where her NIHSS score was 16.

MRI demonstrated restricted diffusion in the left corona radiata (Fig. 1A, B) with an infarct volume of less than $20 \mathrm{cc}$. There was no evidence of hemorrhage. Magnetic resonance angiography showed complete occlusion of the mid-M1 segment of the left middle cerebral artery (MCA; Fig. 1C). The patient was emergently transferred to the neuroendovascular suite, where intra-arterial therapy commenced 5 hours and 25 minutes after symptom onset. Catheter-based angiography confirmed complete left mid-M1 segment occlusion (arterial occlusive lesion $[\mathrm{AOL}]=0$, TICI = 0; Fig. 2A). A $4 \mathrm{~mm} \times 20 \mathrm{~mm}$ Solitaire device was deployed (Fig. 2B) across the occlusive lesion at 6 hours and 20 minutes following symptom onset. Following a single pass of the Solitaire device, angiography confirmed virtually complete recanalization of the left MCA $(\mathrm{AOL}=\mathrm{III}, \mathrm{TICI}=3$; Fig. $2 \mathrm{C})$. The stent/clot combination was extracted. Gross analysis of the Solitaire device demonstrated clot fragments within the stent retrieval system (Fig. 3).

Post-procedurally, the patient was admitted to the neurosciences intensive care unit for further monitoring. After CT scanning of the head demonstrated no hemorrhage 24 hours after rt-PA administration, the patient was started on systemic anti-coagulation given her history of atrial fibrillation for secondary stroke prevention. She was discharged to a rehabilitation center on hospital day 6 with a NIHSS score of 5 (mild word-finding difficulty; mild right face, arm, and leg weakness; mild dysarthia).

\section{Conclusions}

High recanalization rates and good clinical outcome rates are found in patients treated with stentrievers. Ongoing and planned clinical trials for the Trevo and Solitaire devices will further define and confirm their efficacy.

\section{References}

1. Feigin VL, Lawes CMM, Bennett DA, Anderson CS. Stroke epidemiology: a review of populationbased studies of incidence, prevalence, and case-fatality in the late 20th century. Lancet neurology. 2003; 2:43-53. [PubMed: 12849300]

2. Feigin VL. Stroke epidemiology in the developing world. The Lancet. 2005; 365:2160-2161.

3. Liu M, Wu B, Wang WZ, Lee LM, Zhang SH, Kong LZ. Stroke in China: epidemiology, prevention, and management strategies. Lancet neurology. 2007; 6:456. [PubMed: 17434100]

4. Marler J, Tilley B, Lu M, Brott T, Lyden P, Grotta J, et al. Early Stroke treatment associated with better outcome The NINDS rt-PA Stroke Study. Neurology. 2000; 55:1649-1655. [PubMed: 11113218]

5. Rha JH, Saver JL. The impact of recanalization on ischemic stroke outcome a meta-analysis. Stroke. 2007; 38:967-973. [PubMed: 17272772] 
6. Hacke W, Donnan G, Fieschi C, Kaste M, Von Kummer R, Broderick J, et al. Association of outcome with early stroke treatment: pooled analysis of ATLANTIS, ECASS, and NINDS rt-PA stroke trials. Lancet. 2004; 363:768. [PubMed: 15016487]

7. Smith W. Safety of mechanical thrombectomy and intravenous tissue plasminogen activator in acute ischemic stroke. Results of the multi Mechanical Embolus Removal in Cerebral Ischemia (MERCI) trial, part I. American Journal of Neuroradiology. 2006; 27:1177-1182. [PubMed: 16775259]

8. Furlan A, Higashida R, Wechsler L, Gent M, Rowley H, Kase C, et al. Intra-arterial prourokinase for acute ischemic stroke. JAMA: the journal of the American Medical Association. 1999; 282:2003-2011. [PubMed: 10591382]

9. Becker KJ, Brott TG. Approval of the MERCI Clot Retriever A Critical View. Stroke. 2005; 36:400-403. [PubMed: 15653576]

10. Bose A, Henkes H, Alfke K, Reith W, Mayer T, Berlis A, et al. The Penumbra System: a mechanical device for the treatment of acute stroke due to thromboembolism. American Journal of Neuroradiology. 2008; 29:1409-1413. [PubMed: 18499798]

11. Smith WS, Sung G, Starkman S, Saver JL, Kidwell CS, Gobin YP, et al. Safety and efficacy of mechanical embolectomy in acute ischemic stroke results of the MERCI trial. Stroke. 2005; 36:1432-1438. [PubMed: 15961709]

12. Grunwald I, Walter S, Papanagiotou P, Krick C, Hartmann K, Dautermann A, et al. Revascularization in acute ischaemic stroke using the penumbra system: the first single center experience. European Journal of Neurology. 2009; 16:1210-1216. [PubMed: 19659754]

13. Coutts SB, Goyal M. When recanalization does not improve clinical outcomes. Stroke. 2009; 40:2661-2661. [PubMed: 19590048]

14. Wechsler LR. Does the Merci retriever work? Against. Stroke. 2006; 37:1341-1342. [PubMed: 16601224]

15. Hussain SI, Zaidat OO, Fitzsimmons BFM. The Penumbra system for mechanical thrombectomy in endovascular acute ischemic stroke therapy. Neurology. 2012; 79:S135-S141. [PubMed: 23008388]

16. TIMI I. The TIMI Trials. N Engl j Med. 1985; 312:932-936. [PubMed: 4038784]

17. Mori E, Yoneda Y, Tabuchi M, Yoshida T, Ohkawa S, Ohsumi Y, et al. Intravenous recombinant tissue plasminogen activator in acute carotid artery territory stroke. Neurology. 1992; 42:976-982. [PubMed: 1579252]

18. Higashida R, Furlan A, Roberts H, Tomsick T, Connors B, Barr J, et al. Trial design and reporting standards for intraarterial cerebral thrombolysis for acute ischemic stroke. J Vasc Interv Radiol. 2003; 14:S493-494. [PubMed: 14514864]

19. Nogueira RG, Lutsep HL, Gupta R, Jovin TG, Albers GW, Walker GA, et al. Trevo versus Merci retrievers for thrombectomy revascularisation of large vessel occlusions in acute ischaemic stroke (TREVO 2): a randomised trial. Lancet. 2012; 380:1231-1240. [PubMed: 22932714]

20. Mendonca N, Flores A, Pagola J, Rubiera M, Rodriguez-Luna D, Miquel MA, et al. Trevo versus Solitaire a Head-to-Head Comparison Between Two Heavy Weights of Clot Retrieval. J Neuroimaging. 2012

21. San Roman L, Obach V, Blasco J, Macho J, Lopez A, Urra X, et al. Single-center experience of cerebral artery thrombectomy using the TREVO device in 60 patients with acute ischemic stroke. Stroke. 2012; 43:1657-1659. [PubMed: 22442176]

22. Liebeskind D, Jansen O, Walker G, Macho J, Killer M, Wahlgren N. P-025 TREVO measures of successful revascularization: defining optimal endpoints for acute stroke in the stentriever era. $\mathrm{J}$ Neurointerv Surg. 2012; 4:A34-A34.

23. Castano C, Dorado L, Guerrero C, Millan M, Gomis M, Perez de la Ossa N, et al. Mechanical thrombectomy with the Solitaire $\mathrm{AB}$ device in large artery occlusions of the anterior circulation: a pilot study. Stroke. 2010; 41:1836-1840. [PubMed: 20538693]

24. Cohen JE, Gomori JM, Leker RR, Moscovici S, Ramirez-Denoriega F, Itshayek E. Recanalization with stent-based mechanical thrombectomy in anterior circulation major ischemic stroke. J Clin Neurosci. 2012; 19:39-43. [PubMed: 22136733] 
25. Kim JE, Kim AR, Paek YM, Cho YJ, Lee BH, Hong KS. Safety and efficacy of mechanical thrombectomy with the Solitaire device in large artery occlusion. Neurol India. 2012; 60:400-405. [PubMed: 22954976]

26. Machi P, Costalat V, Lobotesis K, Maldonado IL, Vendrell JF, Riquelme C, et al. Solitaire FR thrombectomy system: immediate results in 56 consecutive acute ischemic stroke patients. J Neurointerv Surg. 2012; 4:62-66. [PubMed: 21990438]

27. Miteff F, Faulder KC, Goh AC, Steinfort BS, Sue C, Harrington TJ. Mechanical thrombectomy with a self-expanding retrievable intracranial stent (Solitaire $A B$ ): experience in 26 patients with acute cerebral artery occlusion. AJNR Am J Neuroradiol. 2011; 32:1078-1081. [PubMed: 21493763]

28. Mohlenbruch M, Seifert M, Okulla T, Wullner U, Hadizadeh DR, Nelles M, et al. Mechanical thrombectomy compared to local-intraarterial thrombolysis in carotid $\mathrm{T}$ and middle cerebral artery occlusions: a single center experience. Clin Neuroradiol. 2012; 22:141-147. [PubMed: 21971720]

29. Mpotsaris A, Bussmeyer M, Loehr C, Oelerich M, Buchner H, Weber W. Mechanical thrombectomy in severe acute stroke: preliminary results of the Solitaire stent. J Neurol Neurosurg Psychiatry. 2012; 83:117-118. [PubMed: 21212105]

30. Nayak S, Ladurner G, Killer M. Treatment of acute middle cerebral artery occlusion with a Solitaire AB stent: preliminary experience. Br J Radiol. 2010; 83:1017-1022. [PubMed: 21088087]

31. Park H, Hwang GJ, Jin SC, Jung CK, Bang JS, Han MK, et al. A retrieval thrombectomy technique with the Solitaire stent in a large cerebral artery occlusion. Acta Neurochir (Wien). 2011; 153:1625-1631. [PubMed: 21479799]

32. Roth C, Papanagiotou P, Behnke S, Walter S, Haass A, Becker C, et al. Stent-assisted mechanical recanalization for treatment of acute intracerebral artery occlusions. Stroke. 2010; 41:2559-2567. [PubMed: 20947848]

33. Saver JL, Jahan R, Levy EI, Jovin TG, Baxter B, Nogueira RG, et al. Solitaire flow restoration device versus the Merci Retriever in patients with acute ischaemic stroke (SWIFT): a randomised, parallel-group, non-inferiority trial. Lancet. 2012; 380:1241-1249. [PubMed: 22932715]

34. Stampfl S, Hartmann M, Ringleb PA, Haehnel S, Bendszus M, Rohde S. Stent placement for flow restoration in acute ischemic stroke: a single-center experience with the Solitaire stent system. AJNR Am J Neuroradiol. 2011; 32:1245-1248. [PubMed: 21596812]

35. Wehrschuetz M, Wehrschuetz E, Augustin M, Niederkorn K, Deutschmann H, Ebner F. Early single center experience with the solitaire thrombectomy device for the treatment of acute ischemic stroke. Interv Neuroradiol. 2011; 17:235-240. [PubMed: 21696665]

36. Saver JL. Time is brain—quantified. Stroke. 2006; 37:263-266. [PubMed: 16339467]

37. Tonelli MR, Curtis JR, Guntupalli KK, Rubenfeld GD, Arroliga AC, Brochard L, et al. An official multi-society statement: the role of clinical research results in the practice of critical care medicine. American journal of respiratory and critical care medicine. 2012; 185:1117-1124. [PubMed: 22589312]

38. Kavanagh BP. Glucose in the ICU-Evidence, Guidelines, and Outcomes. New England Journal of Medicine. 2012 

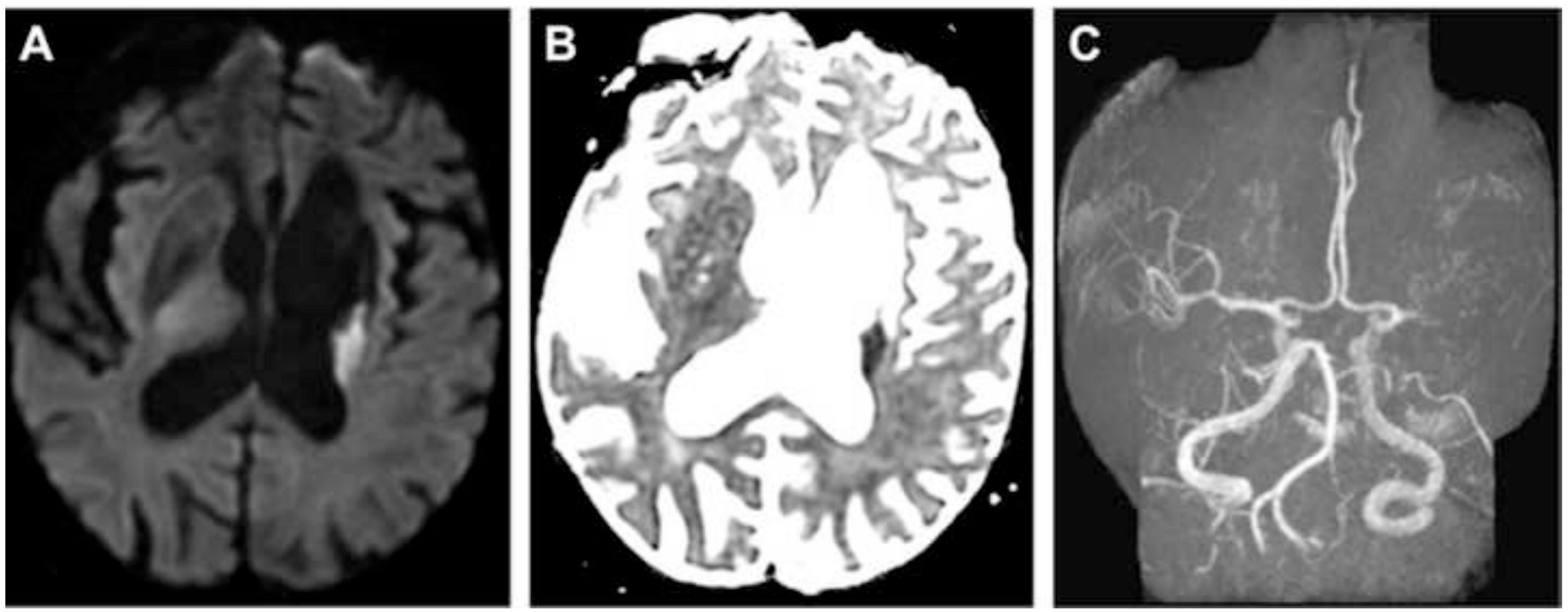

Fig. 1.

Axial MRI showing restricted diffusion on (A) diffusion weighted imaging and (B) apparent diffusion coefficient imaging in the left corona radiate with an infarct volume of less than 20 cc. There was no evidence of hemorrhage. (C) Magnetic resonance angiography showed complete occlusion of the mid-M1 segment of the left middle cerebral artery. 

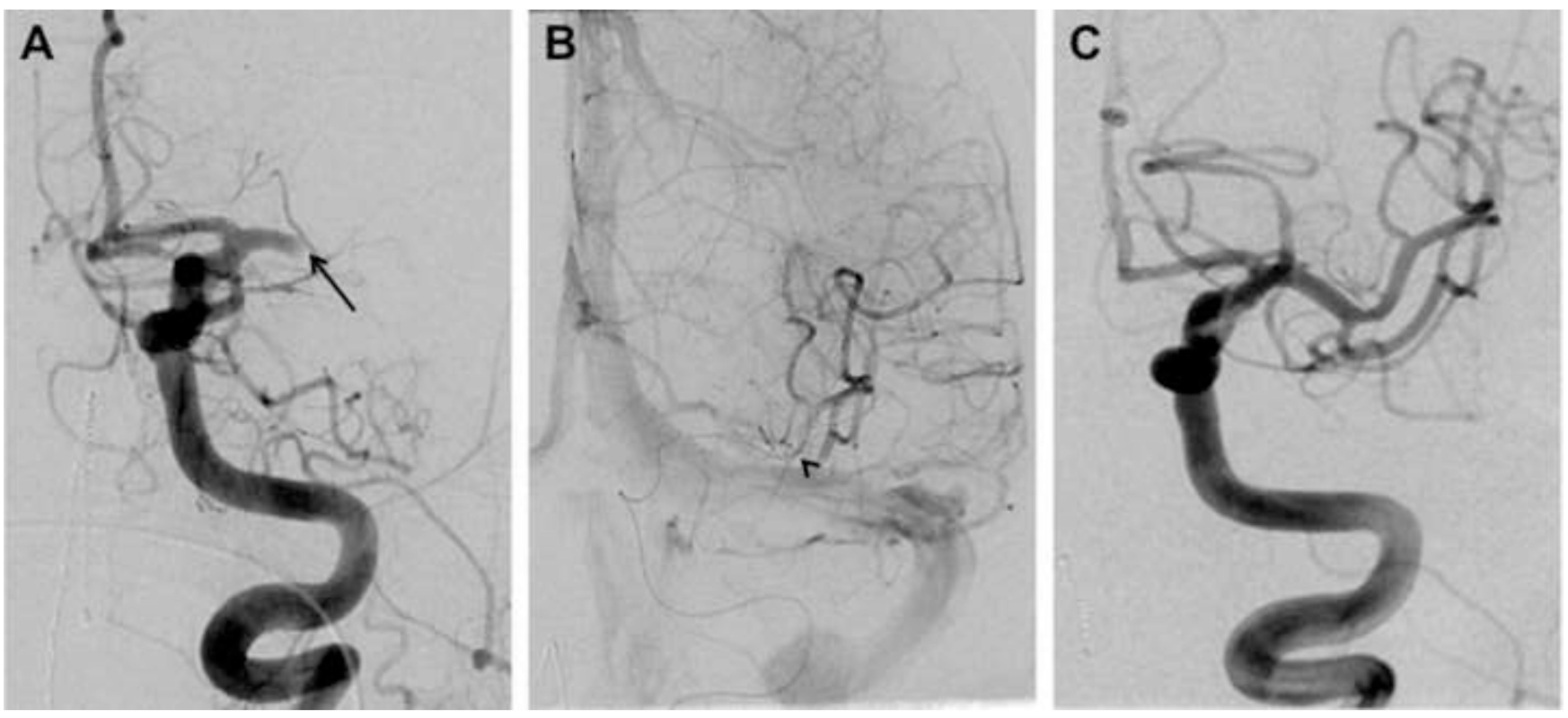

Fig. 2.

(A) Catheter-based angiography showing complete left mid-M1 segment occlusion (Arterial Occlusive Lesion $[\mathrm{AOL}]=0$, Thrombolysis in Cerebral Infarction [TICI] =0). (B) A $4 \mathrm{~mm}$ $\times 20 \mathrm{~mm}$ Solitaire FR Revascularization Device (ev3, Irvine, CA, USA) was deployed across the occlusive lesion at 6 hours and 20 minutes following symptom onset. (C) Following a single pass of the Solitaire device, angiography confirmed virtually complete recanalization of the left middle cerebral artery $(\mathrm{AOL}=\mathrm{III}$, TICI $=3)$. 


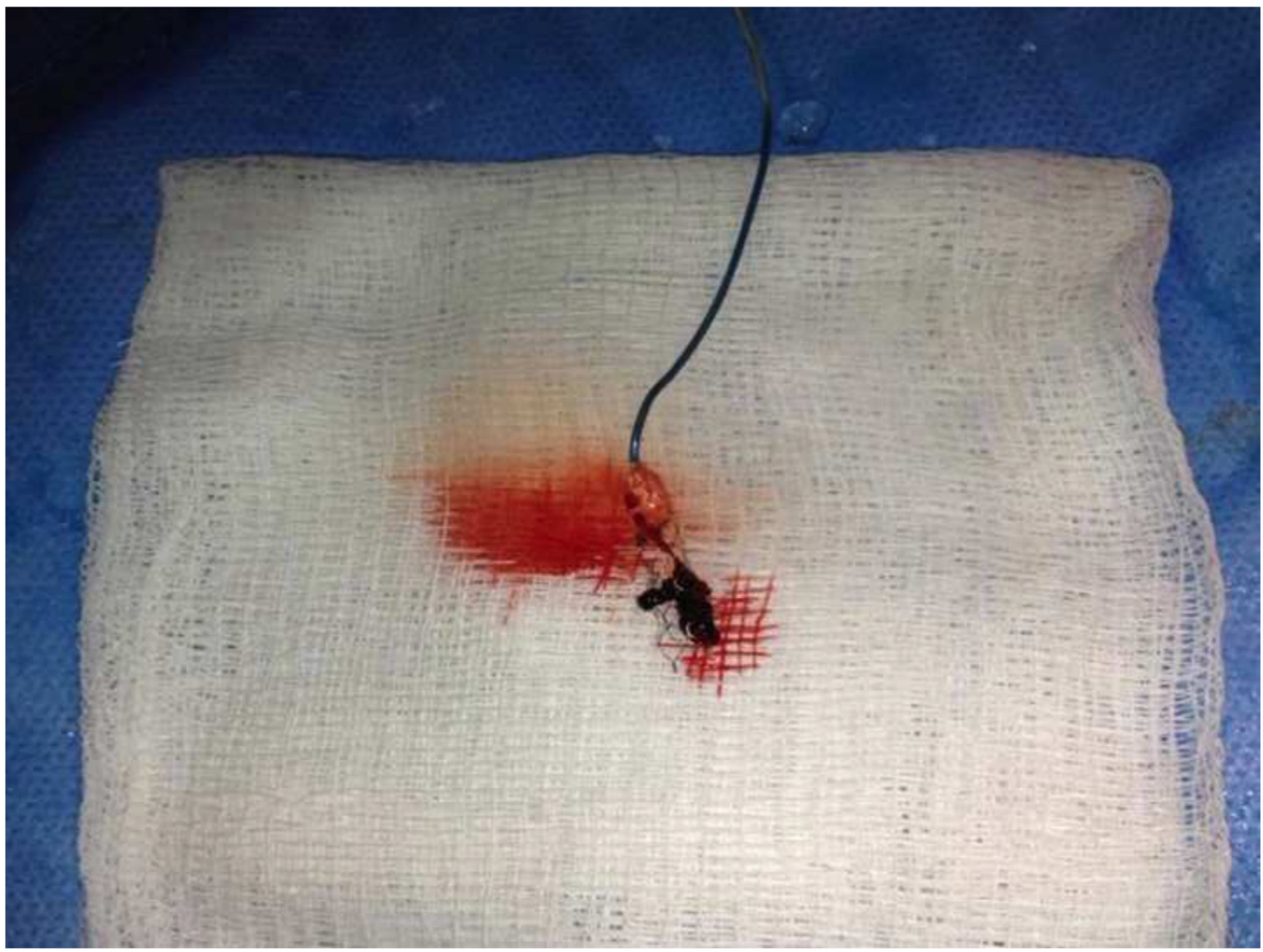

Fig. 3.

Photograph of gross analysis of the Solitaire device (ev3, Irvine, CA, USA) showing clot fragments within the stent retrieval system. 


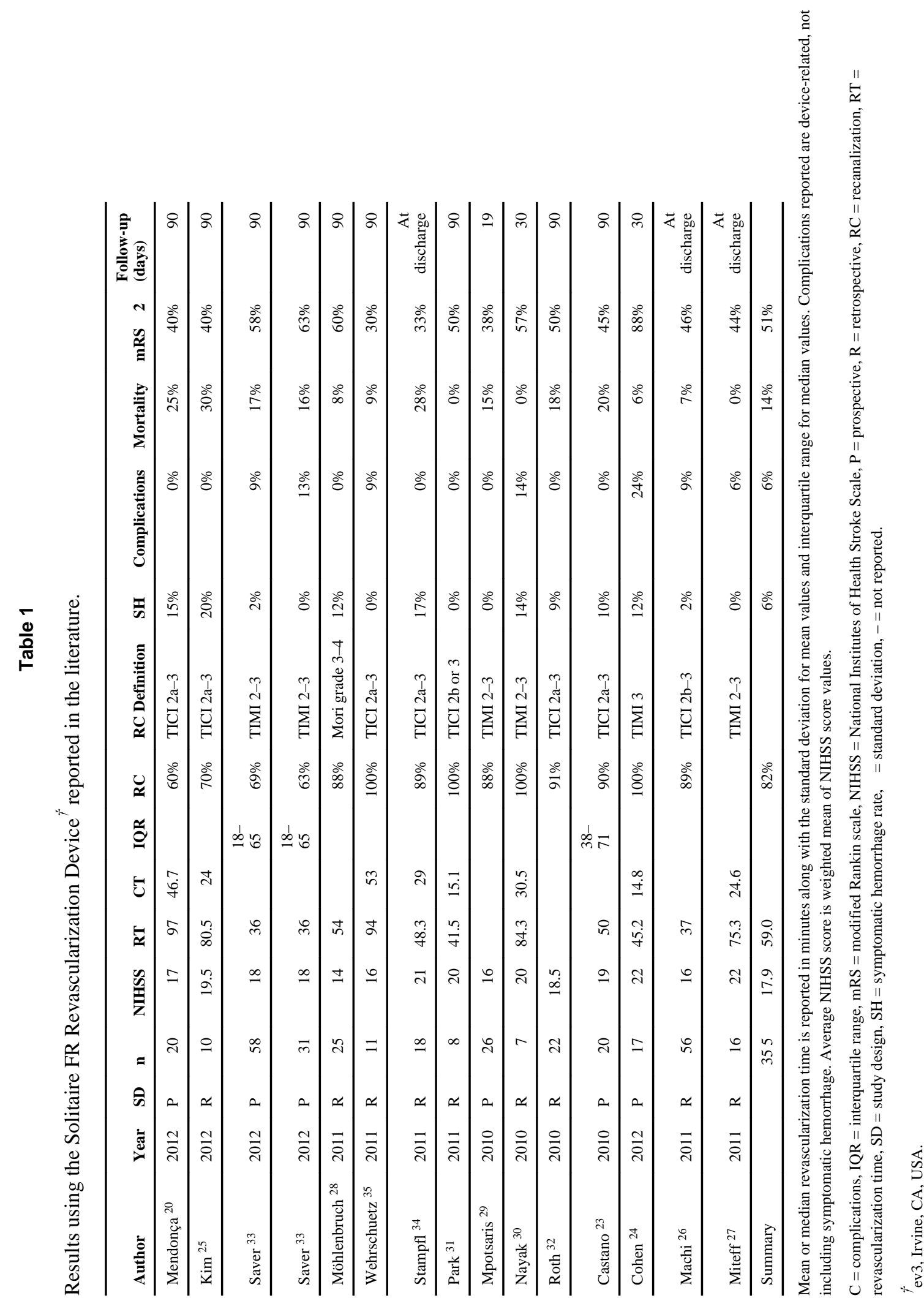




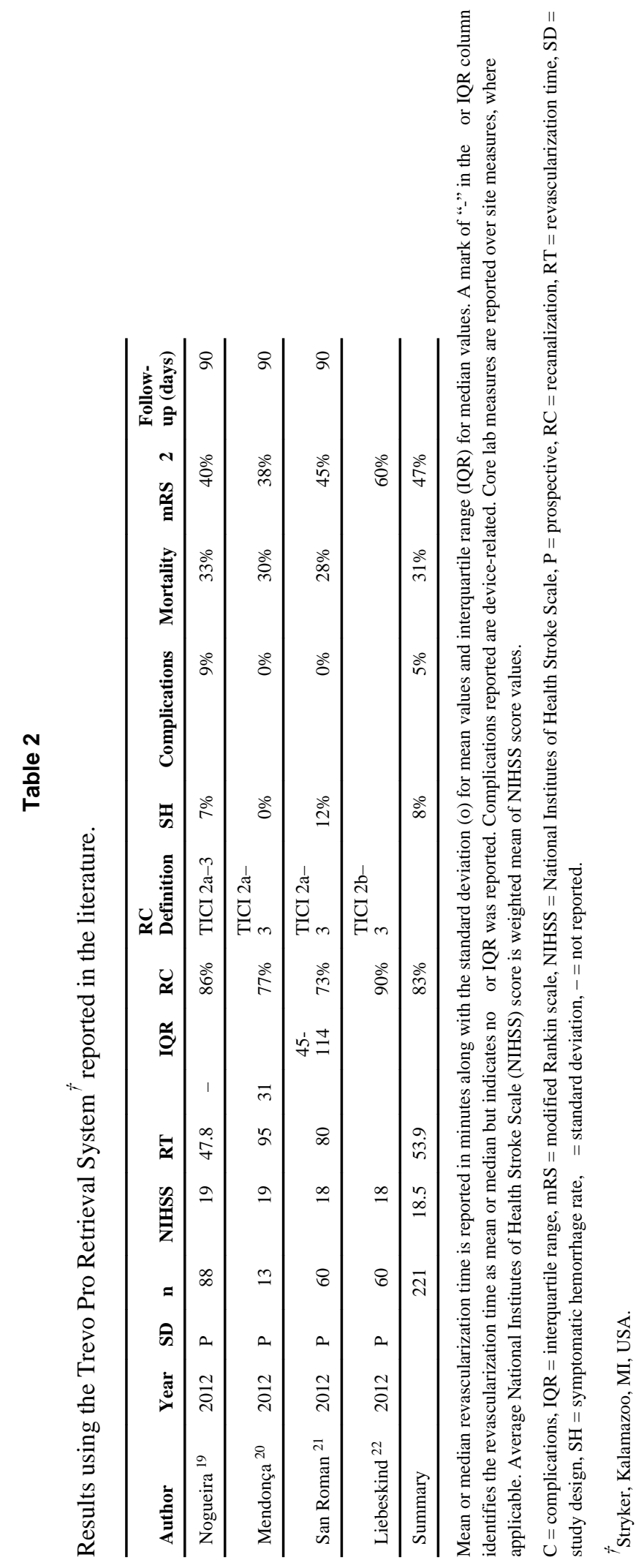

J Clin Neurosci. Author manuscript; available in PMC 2014 October 01. 